\title{
PERBEDAAN GENDER DALAM KECENDERUNGAN UNTUK BERKONFORMITAS PADA SISWA SMA RAKSANA MEDAN
}

\author{
Melda Kristina, Rianda Elvinawaty, Liana Mailani \\ Universitas Prima Indonesia
}

\begin{abstract}
ABSTRAK
Pada masa remaja baik laki-laki maupun perempuan, kedekatannya dengan peer-group sangat tinggi, karena selain ikatan peer-group menggantikan ikatan keluarga, peer-group juga merupakan sumber afeksi, simpati, dan pengertian, saling berbagi pengalaman dan sebagai tempat remaja untuk mencapai otonomi dan independensi. Informasi dari teman-teman tak jarang menimbulkan rasa penasaran yang membentuk serangkaian pertanyaan dalam diri remaja, pertanyaan yang ambigu, dan ketika individu sulit untuk memutuskan atau menjawab pertanyaan tersebut, membuat semakin mudah remaja untuk berkonformitas. Tujuan yang hendak dicapai dalam penelitian ini adalah menguji secara empiris perbedaan kecenderungan melakukan konformitas antara remaja perempuan dengan laki-laki. Hasil penelitian ini menunjukkan bahwa ada perbedaan tingkat konformitas antara remaja perempuan dan remaja laki-laki di Yayasan Perguruan SMA Raksana Medan. Secara spesifik, perempuan memiliki kecenderungan melakukan konformitas yang lebih tinggi daripada laki-laki
\end{abstract}

Kata-kata kunci: Konformitas, gender, remaja

\section{GENDER DIFFRENCES IN THE TENDENCY TO CONFORM AMONG SMA RAKSANA MEDAN STUDENTS}

\begin{abstract}
Attachment with peer-group appears high among male and female adolescents, not only because attachment with the peer-group replaces their attachment with family, but also because peer group provides the need for affection, sympathy, understanding, and mutual sharing of experiences as their source of reaching autonomy and independence. Information from friends often increases adolescents curiosity that creates series of ambiguous questions in the adolescents' mind, and the inability to answer such questions encourage them to conform. The goal of the present research is to test empirically the differences between male and female adolescents in their tendency to conform to members of their peer-group. The results of this research showed that there is a significant difference between male and female adolescents in their tendency to conform to their peer-group among students of Yayasan Perguruan SMA Raksana Medan. Specifically, the female has stronger tendency to conform compared to the male students
\end{abstract}

Keywords: Conformity, gender, adolescents

Pada masa remaja, baik laki-laki maupun perempuan, kedekatannya dengan teman sekelompok (peer-group) sangat tinggi karena selain ikatan peer-group menggantikan ikatan keluarga, mereka juga merupakan sumber afeksi, simpati, dan pengertian, saling berbagi pengalaman dan sebagai tempat remaja untuk mencapai otonomi dan independensi. Informasi dari teman-temannya tersebut tak jarang menimbulkan rasa penasaran yang membentuk serangkaian pertanyaan dalam diri remaja, pertanyaan yang ambigu, dan ketika individu sulit untuk memutuskan atau menjawab pertanyaan tersebut, maka

*Korespondensi mengenai penelitian ini dapat dilayangkan kepada Liana Mailani melalui email: lianamailani@ymail.com semakin mudah individu tersebut untuk berkonformitas.

Penyesuaian remaja terhadap norma dengan berperilaku sama dengan kelompok teman sebaya disebut konformitas (Baron \& Byrne, 2005). Sementara menurut Kim dan Markus (dalam Sears dkk., 2009) konformitas mengandung arti kedewasaan dan kekuatan batin. Kesediaan untuk menyesuaikan diri dengan norma kelompok dianggap sebagai sesuatu yang perlu dan penting bagi kerukunan antar anggota kelompok.

Penelitian membuktikan bahwa tidak semua orang mempunyai tingkat

Rekomendasi mensitasi:

Kristina, M., Elvinawati, R., \& Mailani, L. (2013). Perbedaan gender dalam kecenderungan untuk berkonformitas pada siswa sma Raksana Medan. Psikologia, 8(1), 12-18. 
konformitas yang sama. Sebagian orang lebih mudah berkonformitas dari pada orang lain. Penelitian yang dilakukan oleh Hollander dan Julian (dalam Zikmund, dkk 1984) menunjukkan bahwa ada kecenderungan yang lebih besar bagi perempuan untuk melakukan konformitas dibanding dengan laki-laki. Senada dengan pendapat tersebut, penelitian yang dilakukan Cruthchfield (dalam Zikmund, dkk 1984) menemukan bahwa perempuan lebih cenderung melakukan konformitas di dalam kelompok dibanding laki-laki.

Penelitian membuktikan bahwa tidak semua orang mempunyai tingkat konformitas yang sama. Sebagian orang lebih mudah berkonformitas dari pada orang lain. Penelitian yang dilakukan oleh Hollander dan Julian (dalam Zikmund, dkk 1984) menunjukkan bahwa ada kecenderungan yang lebih besar bagi perempuan untuk melakukan konformitas dibanding dengan laki-laki. Senada dengan pendapat tersebut, penelitian yang dilakukan Cruthchfield (dalam Zikmund, dkk 1984) menemukan bahwa perempuan lebih cenderung melakukan konformitas di dalam kelompok dibanding laki-laki.

Di dalam penelitian ini, kami tertarik untuk mengkaji kembali perbedaan gender dalam kecenderungan melakukan konformitas dalam seting persekolahan. Secara spesifik, kami memeriksa sejauh apa perebedaan siswa perempuan dengan laki-laki dalam hal melakukan konformitas terhadap peer group di mana diri bernaung. Hasil studi ini diharapkan dapat memberikan manfaat bagi pengembangan ilmu psikologi, khususnya psikologi sosial. Penelitian ini juga diharapkan dapat menjadi bahan pustaka dan menjadi bahan masukan bagi penelitian-penelitian selanjutnya pada masa yang akan datang.

\section{Konformitas dan remaja}

Morgan, dkk (dalam Indria \& Nindyawati, 2007) mendefinisikan konformitas sebagai kecenderungan individu untuk mengubah pandangan atau perilaku agar lebih sesuai dengan norma sosial. Definisi lainnya diberikan oleh Asch (dalam Indria \& Nindyawati, 2007) yang menyatakan bahwa konformitas merupakan proses yang bersifat relatif rasional, di mana individu membangun norma dari norma individu lain sebagai acuan untuk dapat berperilaku dengan benar dan pantas. Sarwono (2005) menjelaskan karena kuatnya ikatan emosi dan konformitas kelompok pada remaja, biasanya hal ini menjadi faktor yang menyebabkan munculnya tingkah laku remaja yang buruk. Sementara menurut Wiggins dan Zanden (dalam Indria \& Nindyawati, 2007) konformitas adalah penyesuaian perilaku terhadap normanorma atau standar-standar yang ditentukan oleh orang lain

Dasar utama dari konformitas adalah ketika individu melakukan aktivitas di mana terdapat tendensi yang kuat untuk melakukan sesuatu yang sama dengan yang lainnya, walaupun tindakan tersebut merupakan cara-cara yang menyimpang. Remaja yang mempunyai tingkat konformitas tinggi akan lebih banyak tergantung pada aturan dan norma yang berlaku dalam kelompoknya, sehingga remaja cenderung mengatribusikan setiap aktivitasnya sebagai usaha kelompok, bukan usahanya sendiri. Sears, dkk (2009) menambahkan bahwa kesediaan individu untuk berbeda secara mencolok dengan orang lain berbeda-beda pula. Beberapa orang lebih suka melebur dalam kelompok dan mengikuti opini kelompok, sebagian hanya memilih tampil beda. Maslach (dalam Sears, dkk 2009) mengatakan bahwa orang-orang yang ingin tampil beda disebut dengan desire for individuation (keinginan individuasi), yaitu kesediaan seseorang untuk melakukan hal-hal yang secara publik membedakan mereka dari orang lain atau yang membuat mereka tampil beda.

Ketika memaknai penyesuaian diri sebagai usaha konformitas, menyiratkan bahwa di sana individu seakan-akan mendapat tekanan kuat untuk harus selalu mampu menghindarkan diri dari 
penyimpangan perilaku, baik secara moral, sosial, maupun emosional. Dalam sudut pandang ini, individu selalu diarahkan kepada tuntutan konformitas dan terancam akan tertolak dirinya manakala perilakunya tidak sesuai dengan norma-norma yang berlaku. Secara tradisional, ada dua alasan mengapa seseorang konformitas: (1) untuk menghindari celaan dan (2) untuk mengambil keuntungan dari informasi yang diperoleh dari kelompok referensi (Deutsch dan Gerard dalam Charpenter, 2004).

Menurut Sarwono (2005), faktorfaktor yang mempengaruhi konformitas adalah besarnya kelompok, suara bulat, keterpaduan, status, tanggapan umum, komitmen umum, sementara Menurut Baron \& Byrne (2005), faktor - faktor yang mempengaruhi konformitas adalah kohesivitas, ukuran kelompok, norma sosial deskriptif dan norma sosial injungtif.

Dalam perkembangan sosial, masa remaja lebih melibatkan kelompok teman sebaya dari pada orangtua (Papalia dkk, 2008). Dibanding dengan masa kanakkanak, remaja lebih banyak melakukan kegiatan di luar rumah seperti kegiatan sekolah, ektrakulikuler, dan bermain dengan teman-teman, dengan demikian, pada masa remaja peran kelompok teman sebaya adalah besar (Jahja, 2011). Peplau (dalam Harahaap 2009), berpendapat bahwa aspek-aspek konformitas dapat terlihat dari adanya kepercayaan terhadap kelompok, rasa takut terhadap penyimpangan, kekompakan kelompok, popularitas, simbol status, kekompakan, kesepakatan dan ketaatan dalam kelompok.

Konsep konformitas seringkali digeneralisasikan untuk masa remaja karena dari banyak penelitian terungkap, salah satunya adalah penelitian Berndt, dkk (dalam Santrock, 2005) yang menyatakan bahwa pada masa remaja konformitas terjadi dengan frekuensi yang lebih tinggi dibandingkan dengan masa pertumbuhan lainnya. Hal tersebut dapat dimengerti mengingat pada masa remaja proses pemantapan diri sedang berlangsung sehingga remaja akan lebih rentan terhadap pengaruh perubahan dan tekanan yang ada disekitarnya. Hurlock (1994) menjelaskan kebutuhan untuk diterima dalam kelompok sebaya menyebabkan remaja melakukan perubahan dalam sikap dan perilaku sesuai dengan perilaku anggota kelompok teman sebaya. Demikian pula bila anggota kelompok mencoba menggunakan bahasa yang jorok, mencuri, merusak dan menggolok-olok orang tua dan guru maka, remaja cenderung mengikutinya tanpa memperdulikan akibatnya bagi diri mereka sendiri (Santrock, 2002). Hal tersebut tidak mengherankan, alasannya, terkadang remaja begitu ingin diterima sehingga akan melakukan apapun sesuai penilaian dan persetujuan dari kelompok teman sebaya agar diterima dan diakui keberadaannya dalam kelompok, termasuk melakukan aktivitas yang merusak diri mereka.

Remaja seringkali membangun interaksi sesama teman sebayanya secara khas dengan cara berkumpul untuk melakukan aktivitas bersama dengan membentuk semacam geng. Interaksi antar anggota dalam suatu geng biasanya sangat intens serta memiliki kohesivitas dan solidaritas yang tinggi. Pada masa ini para anggotanya biasanya membutuhkan temanteman untuk melawan otoritas atau melakukan perbuatan yang tidak baik atau bahkan kejahatan bersama dengan kelompok (Ali dan Asrori, 2008).

Remaja yang mulai belajar menemukan nilai-nilai hidup, mempunyai pendirian, serta memilih satu pola hidup dan bersikap kritis, maka tidak jarang ia bentrok dengan otoritas pendidik dan kewibaan orang tuanya sehingga memerlukan teman untuk berbagai semua hal yang terjadi pada dirinya. Remaja dengan ciri-cirinya yang dinamis dan penuh rasa ingin tahu, tidak jarang terjadi pergolakan-pergolakan jiwa atau 'sturm und drang" pada dirinya dengan ciri-ciri pemberontakan, egoisme dan individualisme. Muncul pula aspirasi, ambisi-bambisi besar untuk mendapatkan 
pengakuan dan untuk mencapai suatu tujuan yang besar (Kartono, 2006). Pemberontakan yang dilakukan remaja dengan rasa keingintahuan yang membesar adalah suatu tahap dalam menemukan identitas diri yang baru. Seperti anak muda, remaja cenderung memilih teman yang mirip dengan diri mereka, dan teman saling mempengaruhi untuk menjadi semakin mirip (Berndt dalam Papalia dkk, 2008). Teman tidak harus satu etnis yang terpenting teman memiliki sikap dan performa akademis yang sama dan memiliki status yang mirip dengan kelompok teman sebaya (Berndt \& Perry dalam Papalia dkk, 2008).

Salah satu alasan utama melakukan konformitas adalah demi memperoleh persetujuan atau menghindari celaan kelompok. Hal inilah yang memicu remaja untuk melakukan apa yang dilakukan anggota kelompok dalam berbagai hal (Kartono, 2006). Menurut Santrock (dalam Cyntia, 2007) konformitas kelompok bisa berarti kondisi dimana seseorang mengadopsi sikap atau perilaku dari orang lain dalam kelompoknya karena tekanan dari kenyataan atau kesan yang diberikan oleh kelompoknya tersebut.

Littrell dan Eicher (dalam Workman, dkk 1994) melakukan suatu penelitian tentang pakaian sebagai variabel dalam melihat konformitas atau tidak konformitas remaja terhadap kelompok referensinya. Para peneliti membedakan pakaian yang diterima oleh kelompok referensinya dan pakaian yang tidak diterima oleh kelompok referensinya. Ketika remaja berpakaian dan berpendapat yang sama dengan kelompok referensinya maka, mereka lebih mungkin untuk diterima menjadi anggota kelompok daripada mereka yang tidak sependapat dengan kelompok referensinya. Sipir dan Colquett (dalam Workman, dkk 1994) mengungkapkan bahwa teman adalah sumber paling sering memberikan informasi tentang pakaian yang ingin mereka beli.

Senada dengan pendapat di atas konformitas pada seseorang pun berbeda.
Salah satu pembeda konformitas bisa dilihat dari jenis kelamin, menurut teori Bem tentang Gender Role (dalam Noviantri dkk, 2006). Stereotip perempuan dan laki-laki berbeda. Stereotip laki-laki antara lain memiliki kemampuan memimpin, kompetitif, aktif, dominan, maskulin, atletis, dan independen. Sebaliknya, stereotip perempuan mengutamakan perasaan hangat, mencintai anak-anak, malu, pengertian, lembut, loyal dan simpatetik. Stereotip jenis kelamin memberi nilai tinggi pada laki-laki untuk sifat-sifat yang berhubungan dengan kecakapan seperti kepemimpinan, objektivitas dan kemandirian. Sementara, pada perempuan untuk sifat-sifat yang berhubungan dengan kehangatan dan kelembutan (Sears, dkk dalam Noviantri dkk, 2006).

Penelitian yang dilakukan oleh Eagly \& Carli (dalam Sarwono, 2005) membuktikan bahwa tidak semua orang mempunyai tingkat konformitas yang sama. Di Amerika, perempuan lebih mudah konformitas daripada laki-laki. Kemungkinan di negara berkembang seperti Indonesia kecenderungan ini lebih terlihat. Ada dua kemungkinan mengapa perempuan lebih mudah konformitas daripada laki-laki yaitu, (1) kepribadian perempuan lebih flexible (lentur, luwes), dan (2) status perempuan lebih terbatas sehingga mereka tidak mempunyai banyak pilihan, kecuali menyesuaikan diri pada situasi. Senada dengan ini, penelitian yang dilakukan oleh Edler, dkk (dalam Zikmund, dkk 1984) menunjukkan bahwa kecenderungan perempuan untuk berkonformitas jauh lebih tinggi dibandingkan dengan laki-laki.

Sebuah studi yang dilakukan di Amerika Serikat mengenai kelompok yang ditolak antara perempuan dan laki-laki juga memiliki dampak negatif yang berbeda. Anak laki-laki yang ditolak, terutama yang lebih muda, cenderung menjadi agresif dan antisosial. Sebaliknya, anak perempuan yang ditolak dan anak laki-laki yang lebih tua ditolak cenderung 
menjadi pemalu, terisolasi, tidak bahagia, dan memiliki image diri negatif. Kelompok yang lebih banyak diabaikan atau ditolak yaitu pada usia SMU, mencakup lebih banyak anak laki-laki ketimbang perempuan (Papalia dkk, 2008). Transisi dari sekolah dasar ke sekolah menengah pertama dan dari sekolah menengah pertama ke sekolah menengah atas merupakan sesuatu yang berat bagi kelompok yang ditolak dan yang diabaikan (Papalia dkk, 2008).

Berdasarkan uraian teoritis yang telah dikemukakan diatas maka dapat diajukan hipotesis bahwa kecenderungan remaja perempuan untuk melakukan konformitas terhadap kelompok teman (peer-group) akan lebih tinggi dibandingkan dengan remaja laki-laki.

\section{METODE}

\section{Partisipan}

Populasi dalam penelitian ini adalah siswa-siswi SMA Raksana Medan, yang pada tahun ajaran 2011-2012 berjumlah 535 orang yang dibagi dalam 15 kelas, 5 kelas untuk kelas X, lima kelas untuk kelas XI dan 5 kelas untuk kelas XII. Pengambilan sampel kami lakukan dengan pendekatan incidental, yaitu berdasarkan ketersediaan akses terhadap para partisipan. Berdasarkan ketersediaan tersebut, sebanyak 120 orang siswa-siswi (60 perempuan, 60 laki-laki) kelas $\mathrm{X}$ berpartisipasi di dalam penelitian ini.

\section{Alat ukur}

Alat pengumpulan data yang digunakan dalam penelitian ini adalah dengan menggunakan metode skala. Jenis skala yang diberikan dalam penelitian ini adalah skala langsung yaitu skala yang diberikan secara langsung kepada subjek penelitian. Skala konformitas yang disusun berdasarkan teori yang telah dikemukakan oleh Peplau (dalam Harahap, 2009) berdasarkan beberapa kriteria, yaitu kepercayaan terhadap kelompok, rasa takut terhadap penyimpangan faktor dasar, kekompakan kelompok, populer dan simbol status dalam kelompok. Skala konformitas yang digunakan dalam penelitian ini berisi 30 aitem yang disajikan dalam bentuk pernyataan yang bersifat favourable dan unfavourable dengan pilihan jawaban skala Likert empat titik ( 1 = "Sangat tidak setuju", 2 = "Tidak setuju", 3 = "Setuju", 4 = "Sangat setuju"). Uji coba alat ukur menunjukkan koofisien cronbach's alpha yang reliabel $(\alpha=.86)$. Dengan melihat korelasi setiap aitem dengan skor total, aitem-aitem dalam alat ukur ini menunjukkan kemampuan diskriminasi yang valid (setiap $r=.30-$ .47 , setiap $p<.05$ ).

\section{HASIL}

Kami berhipotesis bahwa siswa perempuan akan memiliki kecenderungan konformitas yang lebih tinggi daripada siswa laki-laki. Untuk mengujikan hipotesis ini, kami lakukan analisis One Way Anova, yaitu teknik analisis data yang digunakan untuk menguji perbedaan ratarata antara dua atau lebih kelompok data yang independen (Priyatno, 2010). Sesuai dengan yang kami hipotesiskan, perempuan memiliki kecenderungan konformitas terhadap peer-group yang lebih tinggi daripada laki-laki, $M_{\text {wanita }}=$ 95.50, $S D_{\text {wanita }}=4.78 ; M_{\text {pria }}=$ $87.18, S D_{\text {pria }}=6.32 ; F(1,118)=$ $66.00 ; p=.001$.

\section{DISKUSI}

Di dalam penelitian ini, kami membandingkan kecenderungan konformitas antara siswa perempuan dengan siswa laki-laki kelas X SMA Raksana Medan. Hasil penelitian ini menunjukkan bahwa siswa perempuan memiliki kecenderungan konformitas yang lebih tinggi daripada siswa laki-laki. Dengan demikian, hipotesis yang kami ajukan, bahwa siswa perempuan akan lebih cenderung melakukan konformitas 
daripada siswa laki-laki dapat diterima atau terdukung oleh data empiris. Selanjutnya, diskusi ini akan kami arahkan pada implikasi konformitas terhadap remaja.

Dari segi definisi, konformitas berarti kecenderungan individu untuk mengubah pandangan atau perilaku agar lebih sesuai dengan norma sosial (Morgan, dkk, dalam Indria \& Nindyawati, 2007). Norma sosial sendiri secara definitif berarti peraturan dan standar-standar yang dipahami oleh anggota-anggota suatu kelompok, yang mengarahkan atau menghambat perilaku tanpa adanya konsekuensi hukum legal (Cialdini \& Trost, 1998). Berdasarkan definisi ini, konformitas dapat berdampak baik atau buruk, tergantung dari normanorma yang berlaku di dalam kelompok. Jika norma-norma yang dibentuk di dalam kelompok bersifat 'membangun', maka dampak konformitas bagi remaja tentunya akan membangun pula. Jadi, jika siswa tergabung dalam kelompok yang secara normatif menganggap menjadi pelajar yang baik sebagai hal yang penting, maka besar kemungkinan siswa-siswa di dalam kelompok tersebut akan berperilaku selayaknya pelajar yang baik. Namun, di sisi lain, jika norma-norma yang dibangun di dalam kelompok bersifat 'merusak', maka dampak konformitas bagi remaja tentunya akan 'merusak' pula. Sebagai contoh, jika kelompok secara normatif menganggap penggunaan obat-obat terlarang sebagai baik, maka besar kemungkinan siswa-siswa di dalam kelompok tersebut untuk menggunakan obat-obat terlarang.

Seperti yang telah kami demonstrasikan di dalam penelitian ini, perempuan lebih rentan terhadap konformitas. Ini berarti bahwa normanorma yang berlaku di dalam kelompok memiliki dampak yang besar terhadap perilaku para pelajar perempuan. Dengan demikian adalah penting untuk memastikan bahwa norma-norma yang berlaku di dalam kelompok siswa-siswa perempuan adalah norma-norma yang 'membangun' dan sesuai dengan tatanan kemasyarakatan. Untuk memastikan hal ini, peran guru (di sekolah) dan orangtua (di rumah) merupakan hal yang krusial. Di sekolah, guru perlu memastikan perkembangan kelompok-kelompok siswa perempuan di sekolah. Jika guru cepat mengidentifikasi kelompok-kelompok yang riskan (misalnya: pengguna obat-obat terlarang, seks bebas, dll.), tindakan preventif pun dapat dilakukan dengan segera. Begitu pula dengan para orangtua. Orangtua perlu berperan aktif dalam mengenal dengan siapa atau dengan kelompok apa anak-anak perempuannya beridentifikasi. Jika anak mulai bergaul dengan kelompok-kelompok riskan, orangtua perlu mengambil tindakantindakan preventif pula. Kerja sama antara guru dan orangtua tentunya akan menghasilkan usaha preventif yang lebih baik lagi.

Selanjutnya, kami menyadari berbagai kekurangan di dalam penelitian ini. Pertama, penelitian ini hanya membandingkan kecenderungan konformitas antara siswa perempuan dengan siswa laki-laki. Dengan demikian, sifat penelitian ini sangatlah umum dan tidak mengacu pada permasalahan yang spesifik. Penelitian selanjutnya mungkin dapat memfokuskan bagaimana peran konformitas terhadap permasalahanpermasalahan remaja. Misalnya, bagaimana peran konformitas terhadap penggunaan obat-obat terlarang, seks bebas, atau perilaku-perilaku delikuen lainnya pada pelajar.

\section{REFERENSI}

Ali, M. \& Asrori, M. (2010). Psikologi remaja. Jakarta: Bumi Aksara.

Baron, R. A., \& Byrne, D. R. (2005). Psikologi Sosial, (Edisi 2). Jakarta: Erlangga.

Charpenter, P, J. (2004). When in Rome: Conformity and the provision of public goods. Journal of Socio-economics, 33, 395-408. 
Cialdini, R. B., \& Trost, M. R. (1998). Social influence: Social norms, conformity, and compliance. In D. T. Gilbert, S. T. Fiske, \& G. Lindzey (Eds.), The handbook of social psychology.

Cynthia, T. (2007). Konformitas kelompok dan perilaku seks bebas pada remaja. Jurnal Psikologi, 1(1), 75-80.

Harahap, C. (2009). Hubungan Kematangan Emosi dengan Konformitas Pada Remaja Laki-Laki MAN 2 Model Medan Pancing. Skripsi (Tidak Diterbitkan). Medan: Fakultas Psikologi UMA.

Hurlock \& Elizabeth, B. (1995). Psikologi perkembangan: Suatu pendekatan sepanjang rentan kehidupan. Jakarta: Erlangga.

Indria, K., \& Nindyati, D. A. (2007). Kajian konformitas dan kreativitas afektif remaja. Jurnal Provitae, 3, 85104.

Jahja, Y. (2011). Psikologi perkembangan. Jakarta: Kencana.

Kartono, K. (2006) Psikologi perempuan: Mengenal Gadis Remaja dan Perempuan Dewasa (Edisi 1). Bandung: Bandar Maju

Novianti, A., Sarwono, W, S., \& Bonnita, A. (2006). Sumbangan Prasangka Gender Pada Sikap Bawahan Terhadap Manajer Perempuan. Jurnal Psikologi Sosial, 12(3),

Papalia, E. D. , Old, Wendkos, S. \& Feldman, D. R. (2008). Human development (edisi 9). Jakarta: Kencana Perdana Media Group.

Priyatno, D. (2010). Teknik mudah dan cepat melakukan analisis data penelitian dengan SPSS. Yogyakarta: Gava Media.

Santrock, J. W. (2002). Life span development, (edisi 5). Jakarta: Erlangga.
Sarwono, W, S. (2005). Psikologi sosial, psikologi kelompok, dan psikologi terapan. Jakarta: Balai Pustaka.

Workman, J. E., \& Johnson, K. K. P.(1994). Effects of conformity and nonconformity to gender-role expectation for dress: teacher versus students. Adolescence, 29(113), 207221.

Zikmund, W, G., Sciglimpaglia D., Lundstrom, J, W., \& Cowell, G, D. 1984. The Effects Of Gender And Product Stereotyping On Conformity Judgements : An Experiment. Advance in Consumer Research, 11, 265-269. 